\title{
Intracellular survival of Renibacterium salmoninarum in trout mononuclear phagocytes
}

\author{
S. K. Gutenberger ${ }^{1}$, J. R. Duimstra ${ }^{2}$, J. S. Rohovec ${ }^{1}$, J. L. Fryer ${ }^{1, *}$ \\ ${ }^{1}$ Department of Microbiology and Center for Salmon Disease Research and \\ ${ }^{2}$ College of Veterinary Medicine, Oregon State University, Nash Hall 220, Corvallis, Oregon 97330-3804, USA
}

\begin{abstract}
In vitro infection of primary cultures of leukocytes from kidneys of rainbow trout Oncorhynchus mykiss showed that Renibacterium salmoninarum, an obligate pathogen of salmonids, survived within the mononuclear phagocytes (MP). Transmission electron microscopy revealed that intracellular survival of the bacterium partially depended on its ability to move from the phagosome and into the cytoplasm. Formalin-killed $R$. salmoninarum also escaped into the cytoplasm, albeit at a slower rate and after sustaining greater cell wall damage, suggesting that the extracellular protein of the bacterium plays a role in intracellular survival. The durability of its cell wall enhanced survival within MP and significant bacterial losses occurred only after 96 h as the MP died and exposed the bacteria to antibiotics in the media. The bacteria appeared to maintain a slow rate of intracellular division, and dividing bacteria were seen in the micrographs through $240 \mathrm{~h}$. Live $R$. salmoninarum were cytotoxic to MP; however, the MP persisted in culture and killed limited numbers of the bacterium. Adherence of the bacterium to the surfaces of lymphocytes and erythrocytes was also noted. An economical and time-saving method for observing and quantifying information obtained from transmission electron microscopy is described. The colony-forming units assay and cell viability counts provided additional information to support the data from electron microscopy.
\end{abstract}

KEY WORDS: Renibacterium. Intracellular pathogen - Mononuclear phagocytes Macrophages Bacterial kidney disease - Transmission electron microscopy

\section{INTRODUCTION}

Renibacterium salmoninarum, the agent of bacterial kidney disease, causes a systemic infection characterized by granulomatous lesions in the kidney and other organs. Histologically, the disease resembles human glomerulonephritis (Young \& Chapman 1978, Bruno 1986). The bacterium is a fastidious Gram-positive actinomycete (Gutenberger et al. 1991) that is not easily controlled with antibiotics in vivo (Elliott et al. 1989). This obligate pathogen successfully perpetuates itself in salmonid populations through the dam, who transmits the bacteria to her progeny via intra-ovum infections (Evelyn et al. 1986, Brown et al. 1994). It is also transmitted through the water from infected to healthy fish (Mitchum \& Sherman 1981, Bruno 1986).

·Addressee for correspondence. E-mail: fryerj@bcc.orst.edu
After infection, death can result within a few months (Fryer \& Sanders 1981) or can occur years later when a latent infection is triggered by adverse environmental conditions, secondary infections, or reproductive stress (Banner et al. 1986, Austin \& Austin 1987).

Renibacterium salmoninarum has been observed in phagocytic cells from infected fish, and is hypothesized to survive within these cells (Young \& Chapman 1978, Bruno 1986). Some attributes of the bacterium, including its resistance to lysozyme, production of catalase, slow rate of replication (generation times of $\sim 24 \mathrm{~h}$; Fryer \& Sanders 1981), cell surface hydrophobicity, autoaggregation (Bruno 1988, Daly \& Stevenson 1990), and prodigious output of a soluble hemolysin/agglutinin (Turaga et al. 1987, Bruno 1988, Daly \& Stevenson 1990, Wiens \& Kaattari 1991), suggest that it could survive and possibly replicate within the mononuclear phagocytes (MP). This is likely why erythromycin, an antibiotic that can concentrate within mammalian 
phagocytes (Brittain 1987), is more effective than other antibiotics against the organism. It would also explain why an effective vaccine has not been developed (Elliott et al. 1989).

The intracellular pathogens of other animals survive within MP by various mechanisms. Some remain within the phagosome and either prevent fusion with lysosomes or resist the enzymes of the resulting phagolysosome (Davis-Scibienski \& Beaman 1980, Kiehlbauch et al, 1985, Sibley et al. 1987, Buchmeier \& Heffron 1991, Dowling et al. 1992). Other intracellular pathogens escape into the cytoplasm to minimize exposure to the products of phagosome-lysosome fusion (Farber \& Peterkin 1991, McDonough et al. 1993). Resistance to the oxygen and hydroxyl radicals released during the respiratory burst of the MP also protects pathogens (Farber \& Peterkin 1991). An understanding of the pathogenic mechanisms of Renibacterium salmoninarum and its interactions with the MP would aid in the development of new strategies for control.

To examine the mechanisms of survival of Renibacterium salmoninarum in MP and the concomitant interactions with other leukocytes, we infected a primary culture of anterior kidney cells from rainbow trout with the bacterium. The anterior portion of the kidney is rich in mononuclear phagocytes, lymphocytes, neutrophils, and other cells of the immune system. Examination of electron micrograph negatives in a microfiche reader permitted quantitative and qualitative observations of virulent $R$. salmoninarum in association with the leukocytes over a period of $10 \mathrm{~d}$. To better understand the mechanisms of virulence, these results were compared with the cell interactions observed with formalin-killed $R$. salmoninarum and the avirulent Arthrobacter globiformis, a related Gram-positive bacterium. In addition to electron microscopic analysis, the number of viable intra- and extra-cellular bacteria were determined by assaying colony-forming units (CFU)

\section{MATERIALS AND METHODS}

Bacteria. A strain and passage of Renibacterium salmoninarum proven to be virulent in vivo was used for this study. The D-6 strain, originally isolated from. Oncorhynchus kisutch (Craig Banner, Dept. Microbiology, Oregon State University, Corvallis, OR, USA), was grown in kidney disease broth with charcoal (Daly \& Stevenson 1985 ) at $15^{\circ} \mathrm{C}$ on a shaker until log phase growth was observed ( $8 \mathrm{~d}$ ). After sampling for counts by the CFU assay, killed $R$. salmoninarum cells were prepared by the addition of formalin $[0.3 \%$ of total volume killed the bacteria as verified by lack of growth on KDM II medium (Evelyn 1977) after $16 \mathrm{wkJ}$. The formalin-killed bacteria were centrifuged $(2000 \times \mathrm{g}$ for 20 minj 4 times with intermediate 3 min vortex mixing in peptone saline $(0.85 \% \mathrm{NaCl}, 0.1 \%$ proteose peptone; Difco, Detroit, MI, USA) to disperse the pellet. The washings removed some, but not all, of the extracellular protein as indicated by a reduced autoaggregation of the formalin-killed bacteria. To infect the leukocytes, the formalin-killed and live $R$. salmoninarum were resuspended in tissue culture media to similar optical densities at $520 \mathrm{~nm}$. Colonies on KDM Il were counted after incubation at $15^{\circ} \mathrm{C}$ for $21 \mathrm{~d}$ and determined to be $1.16 \times 10^{8}$ and $1.62 \times 10^{8} \mathrm{CFU} \mathrm{ml} \mathrm{m}^{-1}$ for the live and formalin-killed $R$. salmoninarum, respectively.

Arthrobacter globiformis (DSM 20124), a taxonomically close relative of Renibacterium salmoninarum, served as a nonpathogenic Gram-positive control and was grown for $24 \mathrm{~h}$ at $26^{\circ} \mathrm{C}$ in tryptic soy broth $\left(4 \mathrm{~g} \mathrm{l}^{-1}\right)$ supplemented with yeast extract $\left(2 \mathrm{gl}^{-1}\right)$. The culture was suspended in medium to yield an infecting dose of $4.4 \times 10^{8} \mathrm{CFU} \mathrm{ml}^{-1}$.

Collection and cultivation of trout leukocytes. Modified Leibovitz's L-15 tissue culture medium with Lglutamine (Flow Laboratories, Inc., McLean, VI, USA) was supplemented with $10 \%$ heat-inactivated fetal bovine serum, $0.8 \%$ glucose, $0.5 \%$ fungizone (GIBCO Laboratories, Grand Island, NY, USA) and buffered with $1 \mathrm{M}$ Tris $\mathrm{HCl}$ to $\mathrm{pH} 7.4$ (referred to as $10 \% \mathrm{~L}-15$ ) (Braun-Nesje et al. 1981).

Eight rainbow trout (Oncorhynchus mykiss), weighing 320 to $658 \mathrm{~g}$, were killed and bled from the caudal vein before the anterior kidneys were aseptically removed. To prevent loss of adherent cells, all cell preparation was performed in polypropylene tubes at $4^{\circ} \mathrm{C}$. The kidney tissues, $13.7 \mathrm{~g}$, were pooled and manually homogenized to single cell suspension in $10 \% \mathrm{~L}$ 15 (supplemented with heparin, $20 \mathrm{U} \mathrm{ml}^{-1}$; penicillinstreptomycin, 500 I.U. $\mathrm{ml}^{-1}$ and $500 \mathrm{mg} \mathrm{ml}^{-1}$; and gentamicin, $\left.250 \mathrm{mg} \mathrm{ml}^{-1} ; \mathrm{pH} 7.4\right)$. To diversify the MP population, peritoneal macrophages were collected after 4 of the 8 fish were injected intraperitoneally with $1 \mathrm{mI}$ Freund's incomplete adjuvant emulsified with the extracellular protein of Renibacterium salmoninarum (Turaga et al. 1987) $3 \mathrm{~d}$ prior to tissue collection (Mbawuike et al. 1986). Cells collected by peritoneal lavage (primarily from 2 responding animals) were added to the kidney cell preparation and accounted for $4.5 \%$ of the total leukocyte preparation. Large clumps were removed from the cell preparation by centrifugation, approximately $20 \times g, 1 \mathrm{~min}$. The supernatant was then pelleted and washed 2 times $(200 \times g$ for $20 \mathrm{~min})$ with $10 \%$ L-15 plus antibiotics. Cells were maintained in suspension, rather than in monolayer cultures, to retain the nonadherent leukocytes and to maximize 
handling ease and counting accuracy. The preparation was diluted to $7.7 \times 10^{7}$ cells $\mathrm{ml}^{-1}$ and rotated $(20 \mathrm{rpm}$ ) in polypropylene tubes on a tissue culture rotator (Scientific Industries, Bohemia, NY) overnight at $15^{\circ} \mathrm{C}$. The cell preparation contained MP, lymphoid cells, neutrophils, and thrombocytes, as well as erythrocytes (the latter were excluded from cell counts) as determined from electron micrographs and differential staining of cell preparations (May-Grunwald stain; Yasutake \& Wales 1983)

Infection of leukocytes. Prior to infection, cells were washed 3 times $\left(200 \times g\right.$ for 20 min at $4^{\circ} \mathrm{C}$ ) with $10 \%$ $\mathrm{L}-15$ to remove the antibiotics, diluted to $2.6 \times 10^{7}$ cells $\mathrm{ml}^{-1}$, and distributed equally into 4 tubes. The cells were pelleted and the supernatant replaced with an equivalent volume of bacteria (live or formalin-killed Renibacterium salmoninarum, or Arthrobacter globiformis) in $10 \% \mathrm{~L}-15$ or with $10 \% \mathrm{~L}-15$ alone (control). At $0 \mathrm{~h}$ ( $29 \mathrm{~h}$ post-collection), there were 4 to 6 bacteria per cell (approximating $\geq 22$ bacteria per MP). The leukocytes were then rotated for $2 \mathrm{~h}$ at $15^{\circ} \mathrm{C}$. After incubation, the tubes were centrifuged at $100 \times \mathrm{g}$ for 5 min to separate the cells from noningested bacteria. This centrifugation step was repeated 3 times with $10 \%$ L-15 containing penicillin G (165 I.U. $\left.\mathrm{ml}^{-1}\right)$ and gentamicin $\left(250 \mathrm{mg} \mathrm{ml}^{-1}\right)$. The cells from each treatment were aliquoted in $1 \mathrm{ml}$ amounts into $2 \mathrm{ml}$ presiliconized microcentrifuge tubes (Slickseal; Island Scientific, Bainbridge Island, WA, USA), capped, and stored at a $25^{\circ}$ angle at $15^{\circ} \mathrm{C}$. The medium was changed at $169 \mathrm{~h}$ by centrifuging $(2000 \times \mathrm{g})$ the tubes to pellet all bacterial cells and leukocytes, removing the supernatant, and replacing it with an equivalent volume of fresh $10 \%$ L-15 plus antibiotics. The media antibiotics prevented the extracellular growth of $R$. salmoninarum as shown by previous tests where viable bacteria at $6.7 \times 10^{7} \mathrm{CFU} \mathrm{ml} \mathrm{m}^{-1}$ in $10 \% \mathrm{~L}-15$ (without leukocytes) were reduced by 3 logs within 12 h by gentamicin or were inhibited by penicillin. Both antibiotics have limited or no penetration into mammalian phagocytic cells (Fountain et al. 1985, Sanchez et al. 1986), a finding verified for intact piscine MP by intracellular survival of the bacteria for $>48 \mathrm{~h}$.

Transmission electron microscopy. At 1, 2, 4.5, 24, $48,96,168$, and $240 \mathrm{~h}, 1$ tube of leukocytes ( $1 \mathrm{ml}$ ) from each treatment was centrifuged to pellet the leukocytes and all extracellular bacteria. The pellet was fixed with $2 \%$ glutaraldehyde (purified Grade I, Sigma) in $0.1 \mathrm{M}$ cacodylate buffer $\left(\mathrm{pH} \mathrm{7.2)}\right.$ at $15^{\circ} \mathrm{C}$. After $1 \mathrm{~h}$, the cells were washed with $0.2 \mathrm{M}$ cacodylate buffer ( $\mathrm{pH} 7.3$ ), spun in a microcentrifuge (model 235B, Fisher Scientific, Pittsburgh, PA, USA) at $22000 \times g$ for $3 \mathrm{~min}$, and the supernatant removed. Each cell pellet was carefully stirred with 2 drops of cooled $2 \%$ agarose (type VII, low gelling temperature $<30^{\circ} \mathrm{C}$; Sigma, St.
Louis, MO, USA) (Watanabe et al. 1988). The agarosecell mixture was spun at $22000 \times g$ for $1.5 \mathrm{~min}$ to concentrate the cells and then allowed to gel on ice before cutting into $1 \mathrm{~mm}$ cubes. Following 2 rinses in buffer, the cubes were post-fixed in aqueous $1 \%$ osmium tetroxide, dehydrated in acetone, and embedded in Medcast-Araldite 502 resin (Ted Pella, Inc, Redding, CA, USA). The blocks were sectioned so that 1 to 2 ribbons of serial sections of leukocytes would be contained on each grid. Between grids, $\geq 20 \mu \mathrm{m}$ of the sampled block was removed so that each grid contained an unique collection of leukocytes. This was done to avoid serial sections of the same leukocytes between grids and to maximize the number of MP examined. The thin sections were stained with saturated aqueous uranyl acetate, and then washed, dried, and stained with bismuth subnitrate (Riva 1974). Specimens were examined with a Zeiss EM 10/A transmission electron microscope at an accelerating voltage of $60 \mathrm{kV}$. All cells within one thin section on a grid were photographed in consecutive micrographs at a magnification of $\times 1250$ to obtain an unbiased sampling. Periodically, serial sections of the MP on a grid would be scanned to verify the location (intra- or extracellular) of the bacteria. More than 200 micrographs, each with 1 to 40 cells, were critically examined to ascertain the effects of treatment at 4.5 and $96 \mathrm{~h}$. A total of another 118 micrographs provided additional information at the other 6 time points. Rather than printing numerous micrographs, the micrograph negatives were examined on a microfiche reader (Model 4020, Micro Design, Hartford, WI, USA) at a magnification of $\times 56000$. Viewing a projected negative image (rather than a positive image of prints) presented no problems and the high magnification permitted more detailed evaluation of bacterial and cellular features. Contact prints of each negative were made and the individual cells were numbered to be used as a map for viewing of the negatives with the microfiche. This permitted identification of each cell, avoided the problem of duplicate readings, and allowed quantification of the observations. The observations were summed in contingency tables and statistical significance was determined by chi-square analysis.

Assessment of cell viability: The MP were rated by the integrity of their plasma membrane, nucleus, and cytoplasm (Ghadially 1988) and ranked as viable, intact-nonviable, or nonintact-nonviable (Table 1).

Assessment of intracellular bacterial location and bacterial cell damage: Intracellular bacteria were recorded as being located in a phagosome when surrounded by a phagosome membrane (>50\% intact), or in the cytoplasm when surrounded by host cell cytoplasm ( $<50 \%$ phagosome membrane contact). Bacteria were considered intact if the integrity of the shape, 
Table 1 Classification of mononuclear phagocytes (MP) used in the electron micrographs. MP were classified according to the integrity of their cellular components (viability; Ghadially 1988) and intactness. Unless otherwise noted, only the MP ciassified as viable or intact-nonviable were used in statistical analysis

\begin{tabular}{|c|c|c|c|}
\hline \multirow{2}{*}{ Classification } & & \multirow{2}{*}{$\begin{array}{l}\text { Integrity of cellular components } \\
\text { Cytoplasm }\end{array}$} & \multirow[b]{2}{*}{ Nucleus } \\
\hline & Plasma membrane ( $\%$ intact $)$ & & \\
\hline Viable & $>95$ & Contiguous & Normal \\
\hline Intact-nonviable ${ }^{a}$ & $60-95$ & Contiguous/disrupted & Normal/pyknotic \\
\hline Nonintact-nonviable & $<60$ & Skeletal, with scant or no organelles & Pyknotic or absent \\
\hline \multicolumn{4}{|c|}{$\begin{array}{l}{ }^{2} \text { The presence of one or more abnormalities in cell integrity classified the MP as nonviable. An MP was deemed intact if the } \\
\text { cytoplasm and plasma membrane were complete enough to retain intracellular bacteria }\end{array}$} \\
\hline \multicolumn{4}{|c|}{$\begin{array}{l}\text { 'These cells were designated MP if intact phagolysosomes containing bacteria were enclosed within a cytoplasmic skeleton } \\
\text { associated with some plasma membrane }\end{array}$} \\
\hline
\end{tabular}

cytoplasm, and cell wall (>50\%) was retained. Any bacteria seen in the nonintact-nonviable MP were considered extracellular.

CFU assay. To determine the number of viable intracellular and extracellular Renibacterium salmoninarum and Arthrobacter globiformis at 24, 48, 96, 168, and $240 \mathrm{~h}, 3$ replicate tubes of leukocytes $(1 \mathrm{ml}$ aliquots) from each treatment were centrifuged at $100 \times g$ for $1.5 \mathrm{~min}$ to pellet the leukocytes. The supernatant, containing extracellular bacteria, was separated into another tube and the bacteria pelleted $(22000 \times g$, $5 \mathrm{~min}$ ). The pellet was washed 3 times with peptone saline to remove antibiotic and then diluted to $1 \mathrm{ml}$ for determination of CFU. To release intracellular bacteria, $1 \mathrm{ml}$ of sterile distilled water was added to the leukocyte pellets to disrupt cellular membranes. This preparation was centrifuged at $22000 \times g$ for $5 \mathrm{~min}$. If cell lysis was incomplete after 3 washings (as determined by light microscopic examination), Triton X-100 (1\% total) was added for $10 \mathrm{~min}$ and the cells were washed again. This procedure ruptured the cells but did not reduce the bacterial CFU. The resulting pellet was then diluted to $1 \mathrm{ml}$. For determination of CFU, the intracellular and extracellular bacterial fractions were diluted in peptone saline $\left(10^{\circ}\right.$ to $10^{-7}$ per $\left.\mathrm{ml}\right)$ and inoculated on duplicate plates of the appropriate medium. Bacterial colonies were counted after maximum growth was obtained ( $6 \mathrm{wk}$ for $R$. salmoninarum and $5 \mathrm{~d}$ for A. globiformis)

Cell enumeration and viability. To assess the effects of the bacteria on leukocyte viability, the cells were enumerated on a Spencer hemacytometer using trypan blue dye exclusion. For each treatment, $20 \mathrm{ml}$ samples were collected at $0,24,48,96,168$, and $240 \mathrm{~h}$ from each of 3 replicate tubes designated for this purpose. Data were log transformed and analyzed using univariate repeated-measures analysis of variance.

\section{RESULTS}

\section{Intracellular survival of Renibacterium salmoninarum in mononuclear phagocytes}

Virulent Renibacterium salmoninarum survived within the MP at a much higher rate than the nonpathogenic Arthrobacter globiformis. R. salmoninarum persisted in high numbers through $96 \mathrm{~h}$, and more than $94 \%$ of

Table 2. Numbers of viable intracellular and extracellular Renibacterium salmoninarum and Arthrobacter globuformis after infection of MP as determined by colony-forming units (CFU) assay. Antibiotics in the media prevented extracellular division of bacteria

\begin{tabular}{|c|c|c|c|c|c|}
\hline \multirow{2}{*}{ Bacterium } & \multirow{2}{*}{$\begin{array}{l}\text { Time } \\
\text { (h) }\end{array}$} & \multicolumn{3}{|c|}{ No. of viable bacteria $( \pm \mathrm{SD})^{\mathrm{d}}$} & \multirow{2}{*}{$\begin{array}{l}\% \text { Intracellular } \\
\text { bacterial cells }\end{array}$} \\
\hline & & Intracellular & ExtracelluJar & Total & \\
\hline \multirow[t]{5}{*}{ R. salmoninarum } & 24 & $3918( \pm 339)$ & $238( \pm 127)$ & $4156( \pm 289)$ & $94( \pm 3)$ \\
\hline & 48 & $4485 i \pm 831)$ & $65( \pm 3)$ & $4550( \pm 828)$ & $99( \pm 0.3)$ \\
\hline & 96 & $2963( \pm 20)$ & $98( \pm 39)$ & $3060( \pm 44)$ & $97( \pm 1)$ \\
\hline & 168 & $73 \cdot(0)$ & $19( \pm 3)$ & $95 \cdot(0)$ & $77 \cdot(0)$ \\
\hline & 240 & $0.4( \pm 0.1)$ & $2( \pm 1)$ & $3( \pm 1)$ & $16( \pm 4)$ \\
\hline \multirow[t]{4}{*}{ A. globiformis } & 24 & $7( \pm 2)$ & $70( \pm 30)$ & $77( \pm 31)$ & $10( \pm 4)$ \\
\hline & 48 & $18( \pm 5)$ & $52( \pm 9)$ & $70( \pm 13)$ & $26( \pm 3)$ \\
\hline & 96 & $1( \pm 0.1)$ & $1( \pm 1)$ & $2( \pm 0.5)$ & $32( \pm 14)$ \\
\hline & 168 & $0( \pm 0)$ & $0.04( \pm 0.03)$ & $0.04( \pm 0.03\}$ & $O( \pm 0)$ \\
\hline
\end{tabular}


the viable bacterial cells were intracellular as determined by CFU assay (Table 2). After 96 h, there was a significant decrease $(p<0.001)$ in the number of viable intracellular bacteria, perhaps attributable to the decline in viable leukocytes (Fig. 1). In contrast, 4 globiformis was rapidly killed or poorly ingested by the MP despite an infecting dose nearly 4 times that of $R$. salmoninarum (Table 2 ).

The observations from electron microscopy confirmed the results from the CFU assay. Examination of several hundred cell profiles from the Arthrobacter globiformis infection at $1,2,4.5,24$, and 48 h revealed only $4 \mathrm{MP}$ with intracellular bacteria and few extracellular bacteria. However, Renibacterium salmoninarum was common in MP, and as many as 11 and 42 bacteria, at 4.5 and $96 \mathrm{~h}$, respectively, were counted in cross sections of MP (Fig. 2).

Renibacterium salmoninarum, whether live or formalin-killed, was resistant to degradation by the MP. At $4.5 \mathrm{~h}, 57 \%$ of the formalin-killed ( $\mathrm{n}=278$ ) and $66 \%$ of the live $(n=119) R$. salmoninarum had intact cell walls. By $96 \mathrm{~h}$, these numbers decreased by only 7 to

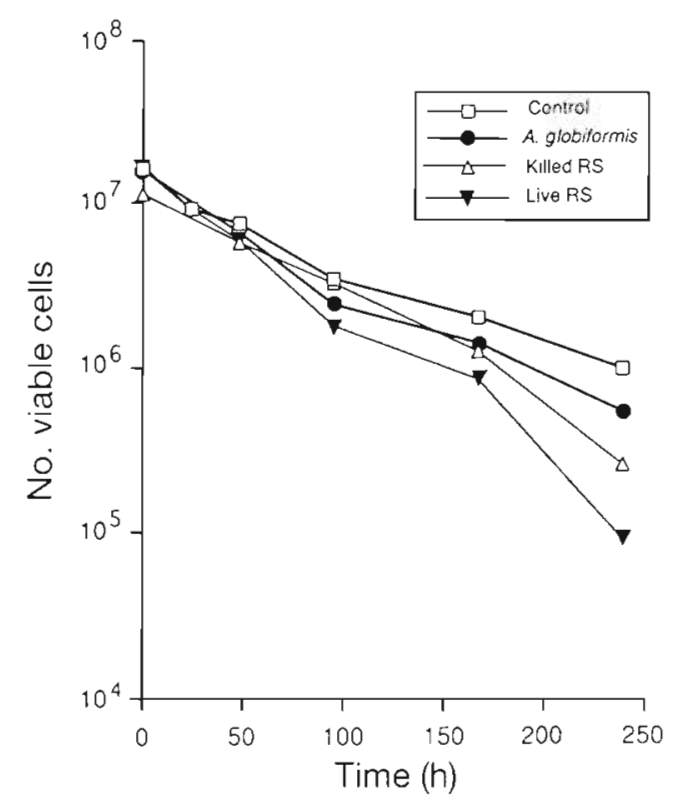

Fig. 1 Effect of treatment and time on the viability of the cultured leukocytes (primarily lymphocytes, MP, neutrophils, and accessory cells). By $96 \mathrm{~h}$, live Renibacterium salmoninarum (RS) significantly reduced the number of viable leukocytes relative to the other treatments $(p<0.01)$. The leukocytes were differentially sensitive to culture conditions, and observations from micrographs showed that the MP persisted significantly longer $(p<0.0001)$ in culture than the other leukocytes. At $96 \mathrm{~h}$, MP comprised nearly two-thirds of the leukocyte population, a reversal of the frequency seen at $4.5 \mathrm{~h}$. Beyond $96 \mathrm{~h}$, the combined effects of live $R$. salmoninarum and culture conditions severely reduced the number of MP. Each data point represents the mean of 3 replicates as determined from trypan blue exclusion assays
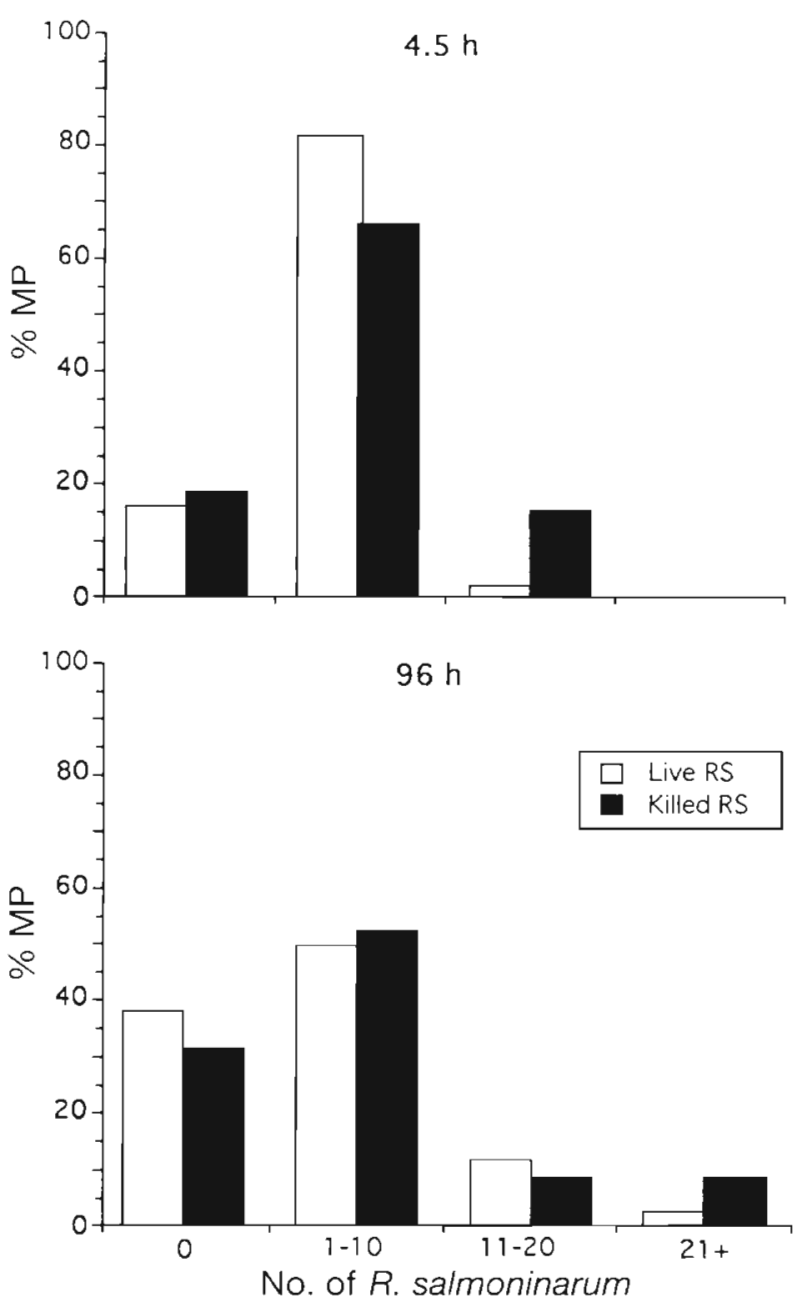

Fig. 2. Numbers of intracellular bacteria observed in crosssection profiles of MP at 4.5 and $96 \mathrm{~h}$ after infection with live or formalin-killed Renibacterium salmoninarum (RS). Intracellular bacteria averaged 3 and 6 (live treatment), and 6 and 8 (formalin-killed treatment) per cell profile, at 4.5 and $96 \mathrm{~h}$, respectively. $\mathrm{N}=40$ to $65 \mathrm{MP}$ per treatment and time

$10 \%$ ( $n=319$ and 292). Based on the average numbers of intracellular bacteria and uninhabited MP (Fig. 2), the MP cleared no more formalin-killed than live bacteria by $96 \mathrm{~h}$. The resiliency of the bacterial cell wall was also revealed by the numerous bacteria seen in the micrographs at 168 and $240 \mathrm{~h}$. At these time points, $R$. salmoninarum cells (live treatment) were found primarily in the culture medium among cellular debris and dissociated pyknotic nuclei; the formalin-killed bacteria were found both within intact MP and extracellularly. Many of the live and formalin-killed $R$. salmoninarum were morphologically intact and retained their coccobacillus shape, complete cell walls, and contiguous cytoplasms despite their former or present intracellular residence and exposure to media antibiotics. 


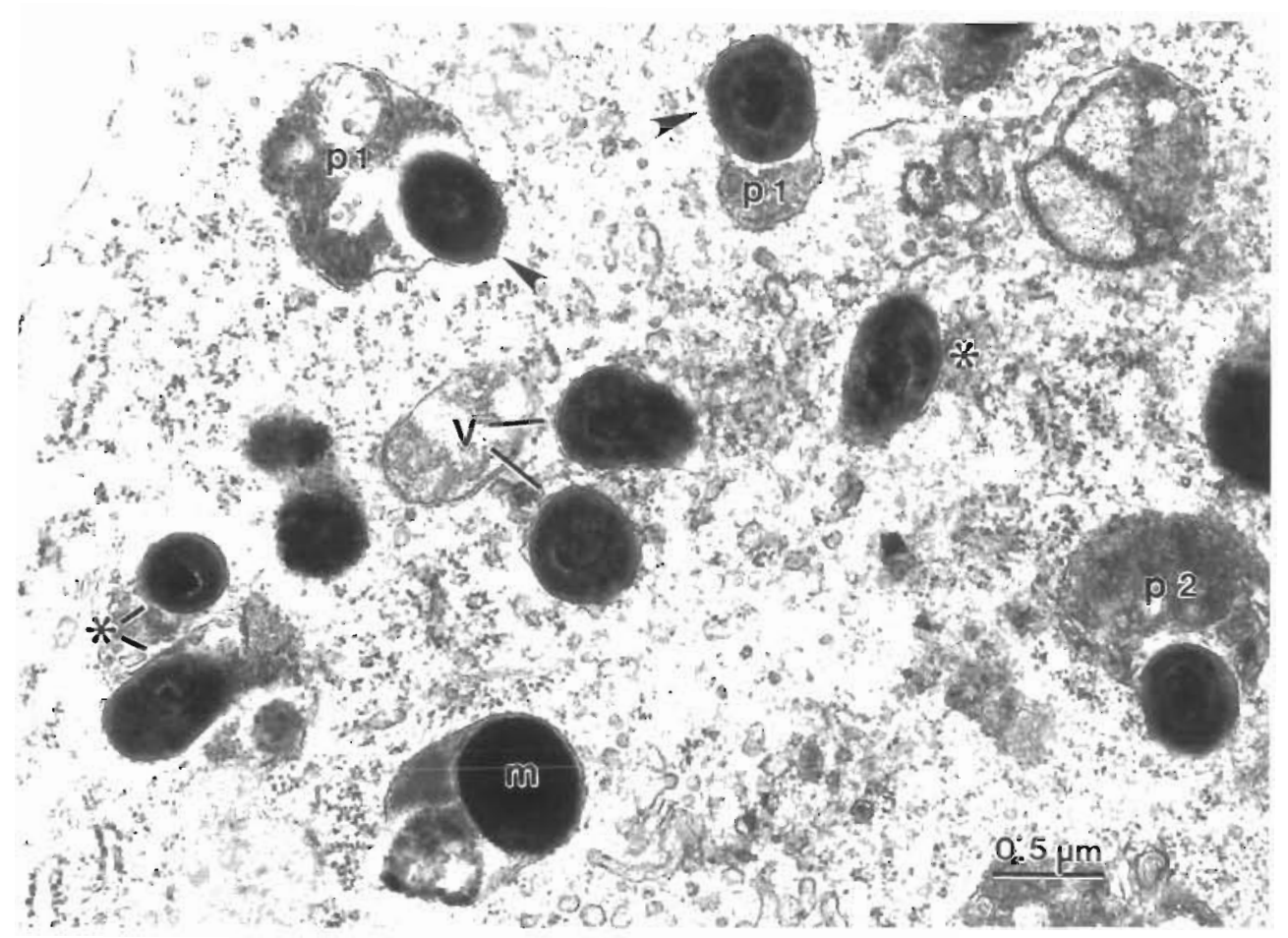

Fig. 3 At $4.5 \mathrm{~h}$ post-infection, live Renibacterium salmoninarum is found in active phagosomes (p1) and in the cytoplasm ( $*$ ) of MP. The bactena may use 1 or 2 methods for escaping the phagosome- lysing the phagosome membrane or budding out of the phagosome into a vesicle with a tightly apposed membrane In this micrograph, the bacteria appear to be in the process of budding out of the phagosome (p1) although there are breaks in the membrane (arrowheads) which could indicate a lytic action. Close examination of 2 bacteria ( $V$ ) reveals that they are mostly enclosed within a fraglle vesicle, the membranes of which probably disintegrate so that the bactena are eventually free within the cytoplasm. The membrane of 1 phagosome (p2) has disintegrated, leaving a bacterium in the cytoplasm. Either mechanism (lysis or budding) would allow the bacteria to escape from. the prmary phagosome and avold or lessen the effects that result after phagosome-lysosome fusion. Melanin. (m) is seen in a deteriorating phagosome

Although the bacterium was durable, at least some MP appeared capable of killing Renibacterum salmoninarum. By $96 \mathrm{~h}$, distorted bacteria appeared in the micrographs and there was a significant increase $(p<0.001)$ in the number of MP lacking bacteria (Fig 2), an indication that $R$. salmoninarum was susceptible to the enzymes in the phagolysosome, where bacterial degradation occurs. In the MP, 3 phenomena were noted: multiple bacteria within large phagosomes, single bacteria contained in vesicles with tightly apposed membranes, and bacteria located free
In the cytoplasm (Figs. $3 \& 4$ ). Both the live and formalin-killed bacterıa appeared to move out of the phagosome, either by budding through the membrane or by partially dissolving and/or mechanically disrupting the enclosing membrane. Fragments of the membrane usually remanned in contact with the bacteria in the cytoplasm. By $4.5 \mathrm{~h}$, most live $R$. salmoninarum cells were located in the cytoplasm (Table 3, Fig 5). In contrast, the formalin-killed $R$. salmoninarum left the phagosome more slowly and at $4.5 \mathrm{~h}$, significantly fewer $(p<0.001)$ were found in the cytoplasm com-

Table 3. Intracellular location of live and formalın-killed Renibacterium salmoninarum (RS) at 4.5 and 96 h post-infection of MP

\begin{tabular}{|c|c|c|c|c|c|c|}
\hline \multirow{2}{*}{ Treatment } & \multirow{2}{*}{$\begin{array}{c}\text { Time } \\
\text { (h) }\end{array}$} & \multirow{2}{*}{$\begin{array}{l}\text { No of MP } \\
\text { observed }\end{array}$} & \multicolumn{4}{|c|}{ Percent frequency of MP population } \\
\hline & & & $\begin{array}{c}\text { with RS in } \\
\text { phaggosome only }\end{array}$ & $\begin{array}{c}\text { with } \geq 50 \% \text { of RS } \\
\text { in phagosome }\end{array}$ & $\begin{array}{c}\text { with } \geq 50 \% \text { of RS } \\
\text { in cytoplasm }\end{array}$ & $\begin{array}{c}\text { with RS in } \\
\text { cytoplasm only }\end{array}$ \\
\hline \multirow[t]{2}{*}{ Live RS } & 45 & 40 & 27.5 & 7.5 & 7.5 & 57.5 \\
\hline & 960 & 5.3 & 34.0 & 5.6 & 15.1 & 45.3 \\
\hline \multirow[t]{2}{*}{ Kelled RS } & 4.5 & 56 & 553 & 232 & 3.6 & 17.9 \\
\hline & 96.0 & 40 & 375 & 100 & 5.0 & 47.5 \\
\hline
\end{tabular}



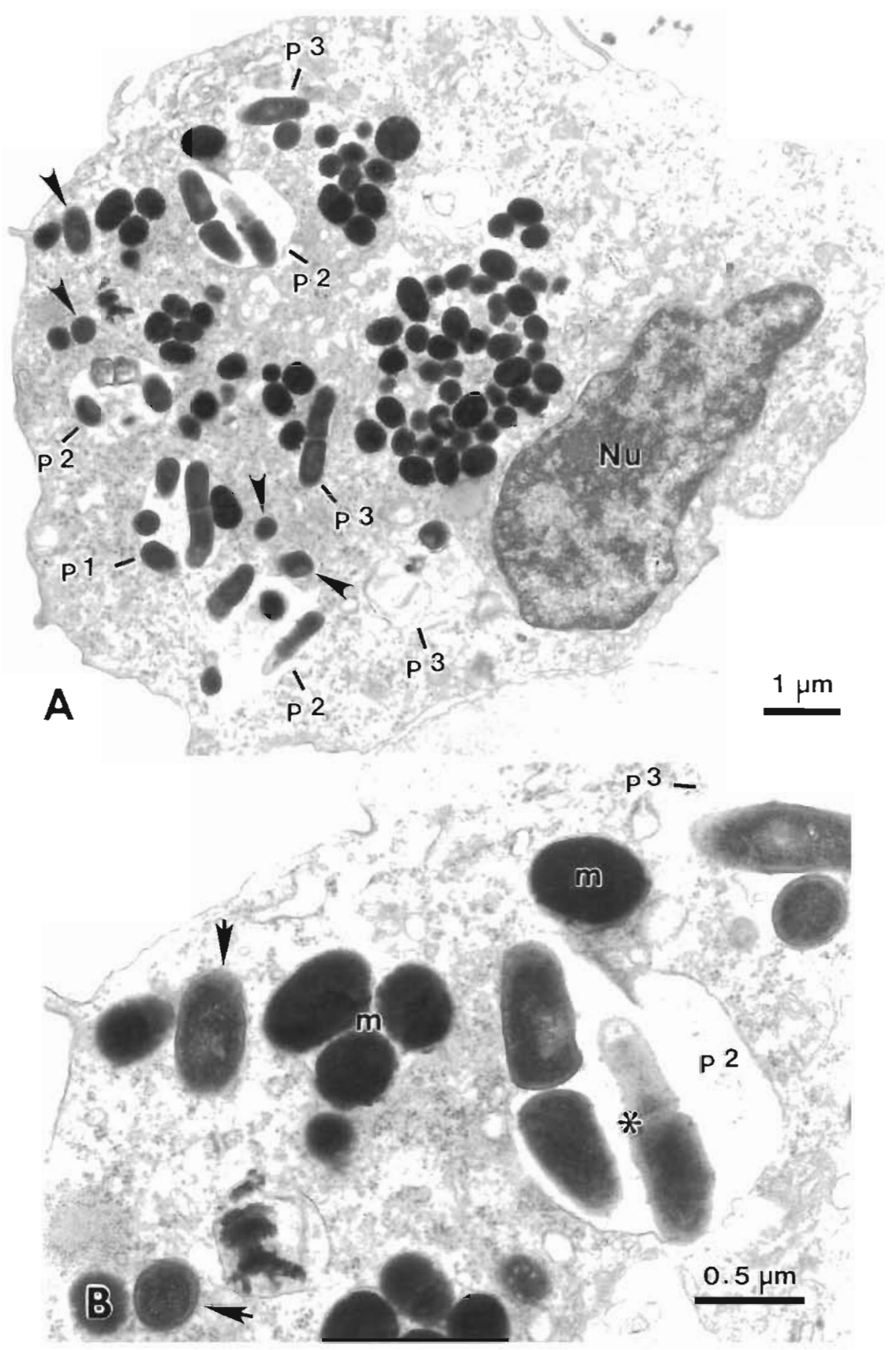

Fig. 4. Formalin-killed Renibacterium salmoninarum, $96 \mathrm{~h}$ after infection, move from the phagosome into the cytoplasm, resisting degradation by the MP. (A) Four bacteria are enclosed in a phagosome with an intact membrane (p1) and 8 are in phagosomes with incomplete membranes (p2). Another 4 bacteria are in transition (p3) between phagosome and cytoplasmic residence as the phagosome membranes have disintegrated, leaving only an empty space around part of the bacteria. Another 4 bacteria are present in the cytoplasm (arrowheads). Extensive deposits of melanin (electron-dense black granules) are present in the cytoplasm and in 2 phagosomes. Nu: nucleus. (B) At an increased magnification, intact bacteria with attached membrane fragments (arrows) in the cytoplasm and in deteriorating phagosomes $(\mathrm{p} 2, \mathrm{p} 3)$ are seen. The bacteria were formalin-killed while in log phase growth; thus many bacteria with transverse cell walls are apparent $(\boldsymbol{*})$ in the micrographs. Melanin (m) is seen in the cytoplasm 


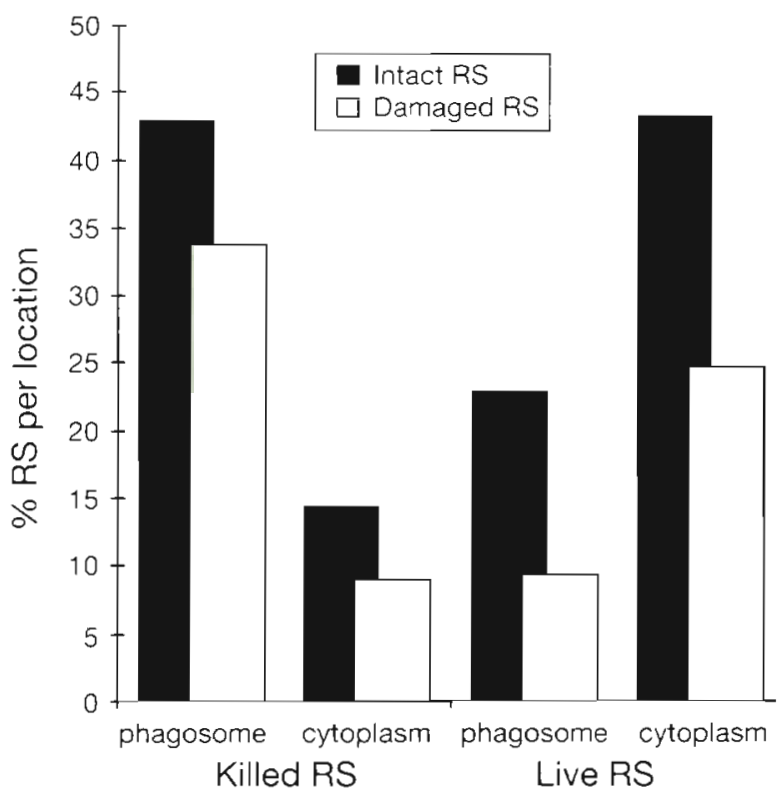

Fig. 5. Total intracellular Renibacterium salmoninarum (RS), intact and damaged, in the phagosome and cytoplasm of MP at $4.5 \mathrm{~h}$. Intracellular bacteria numbered 278 in $51 \mathrm{MP}$ and 119 in $40 \mathrm{MP}$ in the killed and live $R$. salmoninarum treatments, respectively. Data were taken from electron micrographs

pared with the live $R$. salmoninarum treatment. By $96 \mathrm{~h}$, a significant increase in the number of formalinkilled $R$. salmoninarum cells in the cytoplasm was observed ( $p<0.002$ ), equivalent to the number of live $R$. salmoninarum seen at this time. There was no significant change in the number of live $R$. salmoninarum in the cytoplasm between 4.5 and $96 \mathrm{~h}$.

\section{Intracellular replication of Renibacterium salmoninarum}

Replicating forms of Renibacterium salmoninarum were present in the electron micrographs throughout $10 \mathrm{~d}$ (Fig. 6), but the innately slow division of the bacterium and the limited duration of MP in culture prohibited quantification by electron microscopy or CFU assay. Because antibiotics in the media prevented extracellular division, observations of replicating bacteria as late as $240 \mathrm{~h}$ after infection, well beyond the time required for bacterial turnover, suggests that some intracellular division occurred. Throughout the experiment there were never more than 2 replicating bacteria per MP profile in the live treatment, but active replication may have occurred in the unsampled period between 48 and $96 \mathrm{~h}$. In a previous experiment performed under similar conditions, $44 \%$ of the intracellular bacteria $(\mathrm{n}=9)$ were actively replicating at $72 \mathrm{~h}$ in 1 MP profile, indicating that intracellular replication was ongoing.

\section{Interactions of Renibacterium salmoninarum and MP}

Live Renibacterium salmoninarum was significantly more toxic to the MP than formalin-killed $R$. salmoninarum $(\mathrm{p} \leq 0.001)$. Observations from the micrographs showed that, as early as $4.5 \mathrm{~h}$, the populations of MP infected with the live bacteria sustained more damage (represented by nonintact-nonviable cells) than those infected with the formalin-killed bacteria (Table 4). This trend continued through $96 \mathrm{~h}(\mathrm{p} \leq 0.001)$ and was verified by trypan blue exclusion tests ( $p \leq 0.05$; Fig. 1 ). The MP seemed to tolerate only a limited number of live intracellular bacteria and at $96 \mathrm{~h}$ there was an average of $20 R$. salmoninarum per viable MP, as extrapolated from TEM, trypan blue exclusion, and CFU data. After $96 \mathrm{~h}$ it was difficult to find intact MP in the micrographs representing the live treatment. Subsequently, there was a 40 -fold decline in viable $R$. salmoninarum by $168 \mathrm{~h}$ (Table 2), most likely resulting from the release of bacteria from disrupted MP and exposure to the antibiotic-containing medium. The MP appeared to tolerate higher numbers of formalin-killed $R$. salmoninarum and as many as 42 bacteria were observed in cross sections of viable MP at $96 \mathrm{~h}$ in the micrographs. Physical evidence of extensive phagolysosome activity or bacterial-induced damage, such as phagosome membrane lysis, failed to explain the losses of MP in the bacterial treatments.

Throughout the experiment, viable MP actively ingested melanin granules, creating a new subset of melanomacrophages (Fig. 7). The presence of Renibacterium salmoninarum, whether live or formalinkilled, seemed to trigger disruption of melanocytes, the

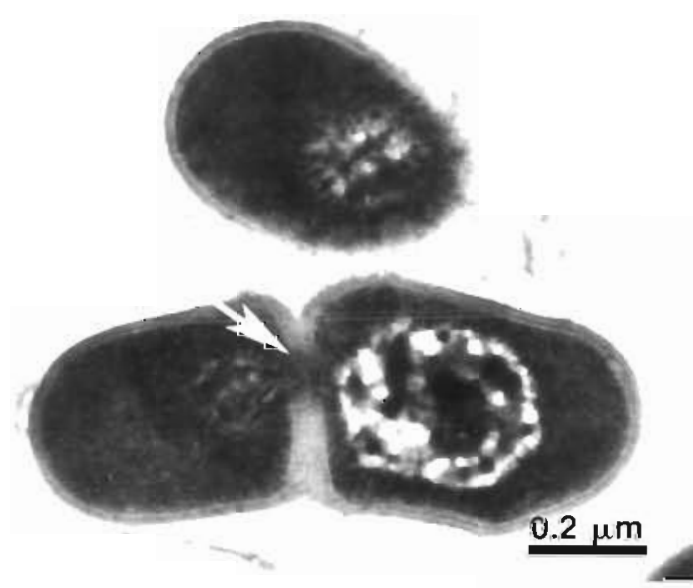

Fig. 6. Replicating Renibacterium salmoninarum was seen at $240 \mathrm{~h}$ and this bacterium, lacking completed cell wall construction (white arrow), was found in a clump of cellular debris. Antabiotics in the media prevented extracellular bacterial division; thus the process of replication must have started in an MP 
Table 4. Effect of treatment on MP viability as described by the frequency of viable, intact-nonviable, or nonintact-nonviable cells. RS: Renibacterium salmoninarum

\begin{tabular}{|c|c|c|c|c|c|}
\hline \multirow{2}{*}{ Treatment } & \multirow{2}{*}{ Time } & \multirow{2}{*}{$\begin{array}{l}\text { No. of cell } \\
\text { profiles }\end{array}$} & \multicolumn{3}{|c|}{ Percent frequency of MP viability ${ }^{\star 2}$} \\
\hline & & & Viable & Intact-nonviable & Nonintact-nonviable \\
\hline \multirow[t]{2}{*}{ Control } & 4.5 & 0 & $N D^{b}$ & ND & ND \\
\hline & 96.0 & 37 & 75.7 & 10.8 & 13.5 \\
\hline \multirow[t]{2}{*}{ Live RS } & 4.5 & 81 & 51.8 & 17.3 & 30.9 \\
\hline & 96.0 & 188 & 22.9 & 21.3 & 55.8 \\
\hline \multirow[t]{2}{*}{ Killed RS } & 4.5 & 78 & 47.4 & 42.3 & 10.3 \\
\hline & 96.0 & 76 & 38.2 & 31.6 & 30.2 \\
\hline \multicolumn{6}{|c|}{$\begin{array}{l}\text { ¿Viable: intact plasma membrane, contiguous cytoplasm, and normal nuclei; intact-nonviable: disrupted plasma membrane, } \\
\text { cytoplasm, or pyknotic nuclei; nonintact-nonviable: disrupted plasma membrane, poorly defined cytoplasm, and pyknotic nuclei }\end{array}$} \\
\hline \multicolumn{6}{|c|}{$\begin{array}{l}\text { Not done. Identification of MP lacking phagosomes, residual bodies, and other characteristic properties was equivocal at this } \\
\text { time point }\end{array}$} \\
\hline
\end{tabular}

repositories of melanin. From micrographs, the frequency of melanomacrophages increased from 9 to $10 \%$ at $4.5 \mathrm{~h}$ to 30 to $32 \%$ at $96 \mathrm{~h}$ in cell populations infected with $R$. salmoninarum. This was nearly double the frequency seen in control treatment populations $(17 \%)$ at $96 \mathrm{~h}$. The presence of melanin in phagosomes and cytoplasm of the MP did not appear to degrade the bacteria (Fig. $7 \mathrm{C}$ ) although it was often seen in active and old phagolysosomes.

\section{Interactions of Renibacterium salmoninarum and other cells}

Phagocytosis of Renibacterium salmoninarum by cells other than MP was not observed. However, as many as 1 to $9 R$. salmoninarum, live or formalin-killed, adhered to the plasma membranes of lymphocytes at $4.5 \mathrm{~h}$ (Fig. 8). Bacteria were found tucked within the membrane invaginations of the lymphocytes and possibly penetrated into the cytoplasm of the cells; however, the latter observation could not be verified because serial sections of these cells were not examined. More rarely, $R$. salmoninarum was found embedded on the surface of erythrocytes. Some cells (lymphocytes, plasma cells, and erythrocytes) with surface-embedded bacteria were phagocytosed by MP (Fig. 9).

\section{DISCUSSION}

For years, chronic infections of Renibacterium salmoninarum have plagued salmonids and reduced survival of these fish. The bacterium has developed survival strategies that allow it to persist within fish populations for generations (Fryer \& Sanders 1981) and elude control by chemotherapy and vaccines (Elliott et al. 1989). In those animals which do not succumb to acute infections, the bacterium appears to remain dormant or to be controlled by the immune system of the host. However, long-standing infections of $R$. salmoninarum often culminate during reproduction and infect future progeny (Evelyn et al. 1986). We demonstrated virulence characteristics of $R$. salmoninarum that allow avoidance of immune defenses and verified that it survives within MP despite the attempts of this cell to eliminate it.

We found that the cell wall of Renibacterium salmoninarum contributes to bacterial survival and, thus, constitutes a virulence factor. This was verified by contrasting $R$. salmoninarum with Arthrobacter globiformis, a close phylogenetic relative (Stackebrandt et al. 1988, Gutenberger et al. 1991, Gutenberger 1993). Although significant similarities exist in the cell wall construction, 16S rRNA, and biochemistry between $R$. salmoninarum and A. globiformis (Sawai et al. 1976, Goodfellow et al. 1985, Jones \& Krieg 1986, Gutenberger 1993), the differences in their internalization and resistance to enzymatic degradation by MP are striking. Both live and formalin-killed $R$. salmoninarum, but not $A$. globiformis, were readily phagocytosed by MP in the absence of complement, and often retained intact cell walls for up to $240 \mathrm{~h}$. In this respect, $R$. salmoninarum resembles Mycobacterium tuberculosis, another intracellular pathogen that, viable or not, has a formidable cell wall that resists degradation by the MP (McDonough et al. 1993). The durability of $R$. salmoninarum might be attributed to its cell wall, unique among Gram-positive bacteria, which contains a rare amino sugar (Kusser \& Fiedler 1983) and is highly resistant to in vitro lysis (lysozyme and pressures of 20000 psi followed by detergent and proteinase K; Gutenberger et al. 1991).

Although its cell wall is durable, Renibacterium salmoninarum was not completely resistant to the enzymes of the phagolysosome. This explains the necessity for the rapid escape of the bacteria from phagosomes. Some bacteria appeared to bud out of the 


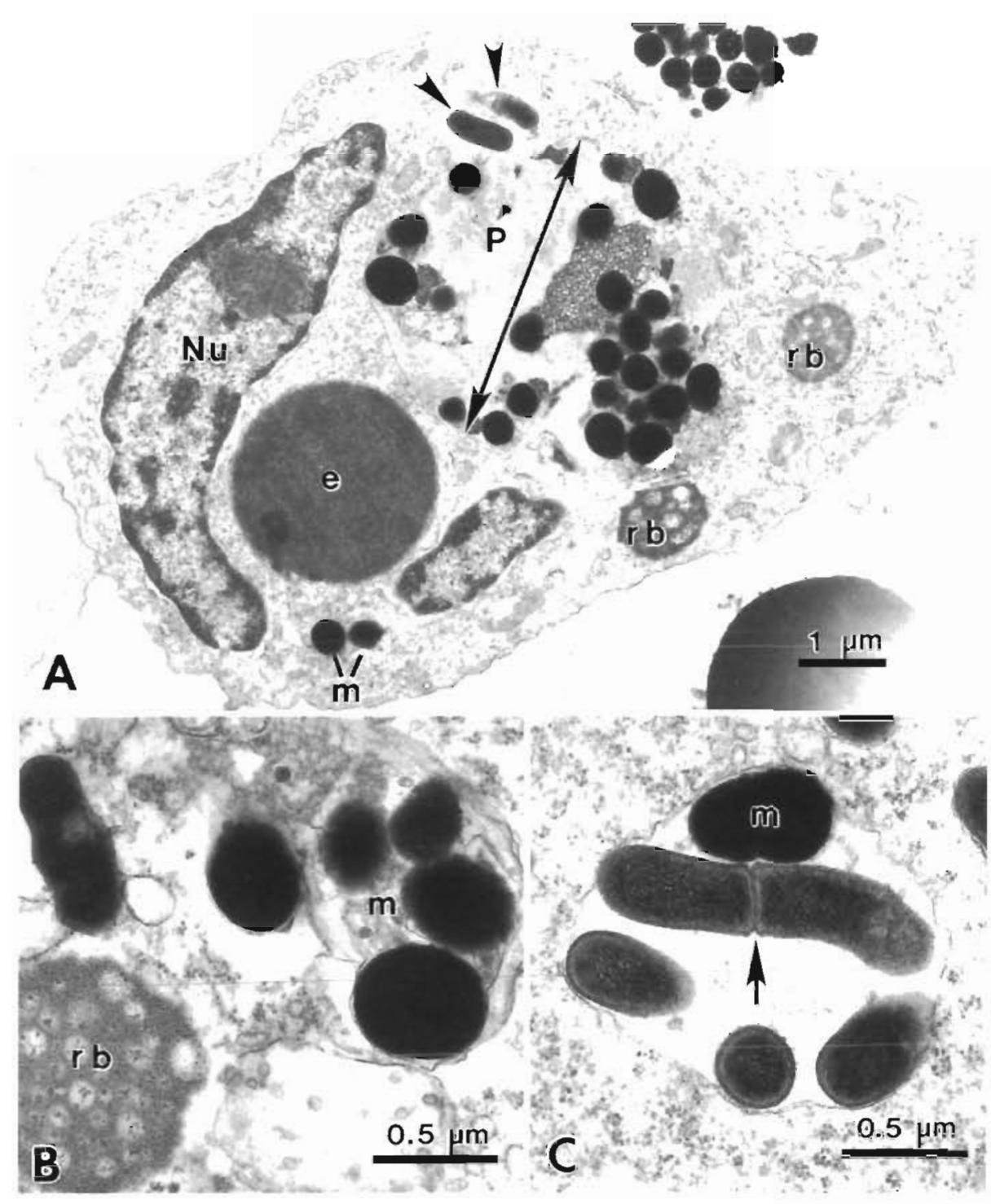

Fig. 7. (A) At 96 h, this intact, but non-viable, melanomacrophage (MP) contains bacteria (arrowheads) and a large deteriorating phagosome (P) with melanin. By this time, many MP had ingested melanin that had been released from melanocytes or other disrupted melanomacrophages. Melanin may help protect the scavanging MP from the enzymes exuded from piscine neutrophils which, having little or no phagocytic capability, appear to kill micro-organisms extracellularly (Ellis 1982, Rowley et al. 1988. Ferguson 1989). Two melanin granules (m) and 2 residual bodies (rb) are seen in the cytoplasm, as is a cross section of a dead erythrocyte (e). Nu: nucleus. In (B), a residual body (rb), an old phagolysosome that has completed degradation of its contents (Ghadially 1988), is evidence of the activity of the MP. By $96 \mathrm{~h}, 48$ to $56 \%$ of the infected MP had residual bodies, an increase from $4.5 \mathrm{~h}(9$ to $12 \%$ ). Melanin (clustered around $\mathrm{m}$ ) was often seen in areas of degradation although it had no apparent effect on closely associated Renibacterium salmoninarum. (C) Even the formalin-killed bacterium seen here (arrow) appears intact (the indistinct edges are the result of the juxtaposition of the bacteria to the knife edge during sectioning)

phagosome and pinch off some of the membrane to create a bacterial-containing vesicle with tightly apposed membranes. This is a mechanism that is used by Mycobacterium tuberculosis to avoid the killing proteins incorporated into the phagosome after fusion with the lysosomes. Later, the vesicle membranes disappear leaving the bacteria in the cytoplasm (McDonough et al. 1993), a situation that was noted in our micrographs. Alternatively, many of the bacteria appeared to escape into the cytoplasm by disrupting and possibly lysing the phagosome membrane. Listeria monocytogenes, another intracellular pathogen, enlists this tactic through an apparent hemolysin-induced lysis of the phagosome (Farber \& Peterkin 1991). Regardless of the mechanism used, budding or membrane lysis, the transition of $R$. salmoninarum from the phagosome into the cytoplasm undoubtably contributes to its survival within the MP. The resistance of 


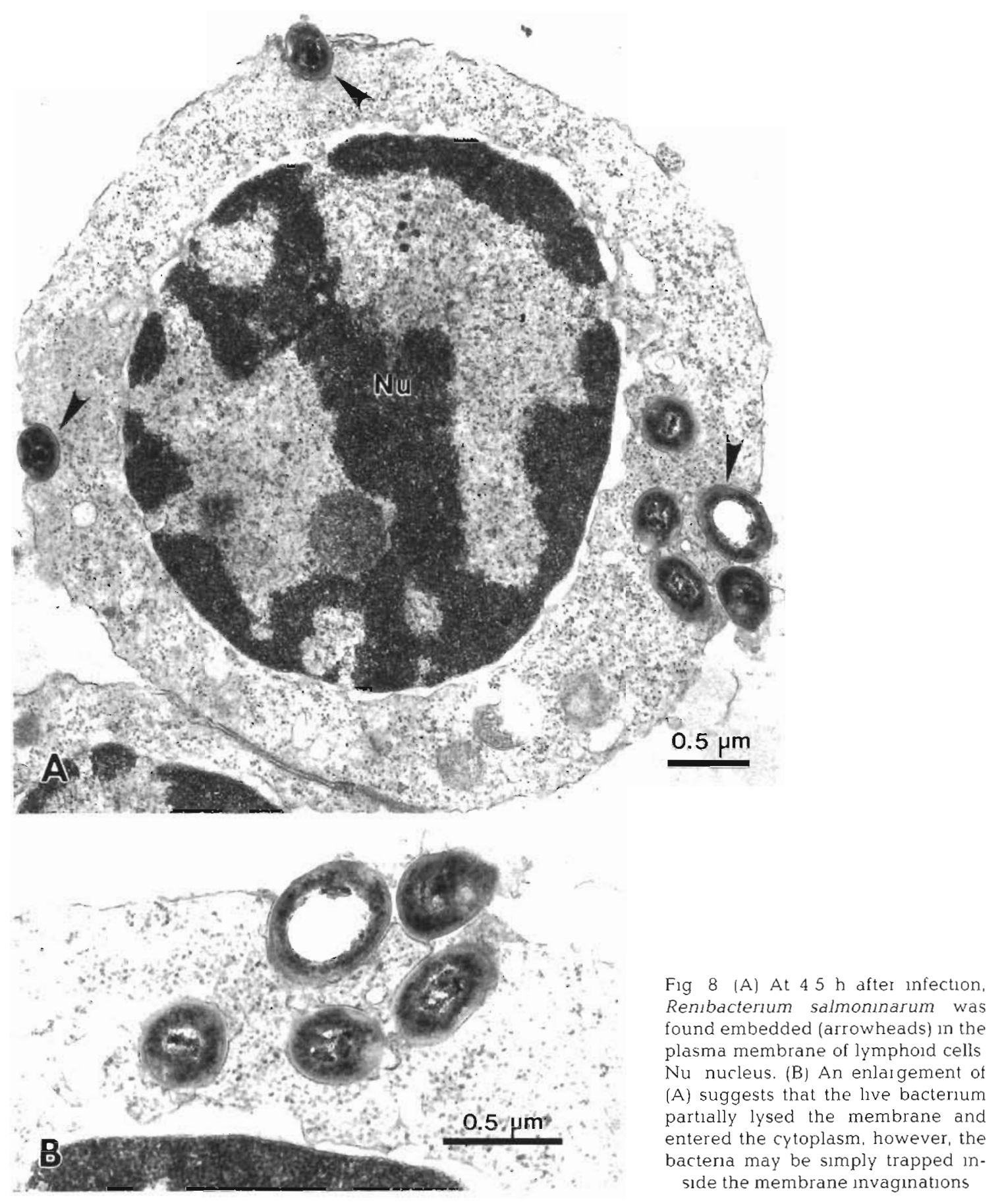

R. salmoninarum to lysozyme (Fryer \& Sanders 1981), the endogenous enzyme in the cytoplasm of MP, further supports this strategy for intracellular survival. It is notable that the formalin-killed $R$. salmoninarum also retained, in reduced capacity, the abllty to move from the phagosome into the cytoplasm, despite preinfection treatment with formalin and salıne washes

Another factor contributing to intracellular survival and disease transmission might be the lengthy gen- eration time of Renibactenum salmoninarum which is $\geq 18 \mathrm{~h}$ at 15 to $18^{\circ} \mathrm{C}$ even in aerated culture medium (Fryer \& Sanders 1981, S. Gutenberger unpubl, data). The bacteria appeared to replicate slowly withun MP, as noted by sightings in the micrographs at $240 \mathrm{~h}$ postinfection. The slow replication of $R$. salmoninarum probably contributes to its success as a pathogen for 2 reasons. Dormant or slowly growing bacteria are resistant to many antibiotıcs that target actively replicating 


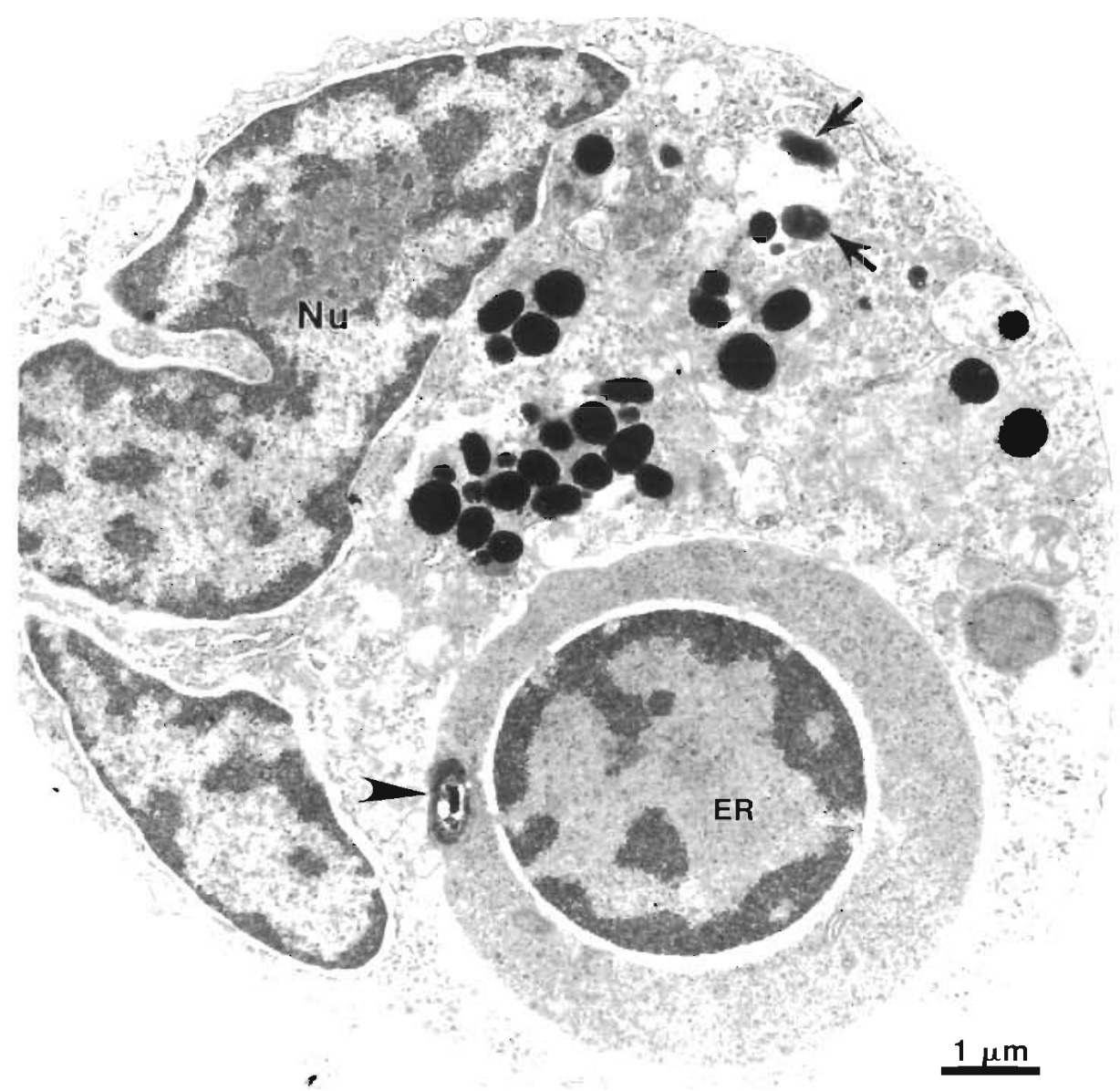

Fig. 9. Bacteria embedded in the membranes of erythrocytes and lymphocytes seemed to induce phagocytosis of the affected cells by MP. At $4.5 \mathrm{~h}$, an immature erythrocyte (ER) with a membrane-embedded Renibacterium salmoninarum (arrowhead) has been phagocytosed by an active melanomacrophage which has also engulfed other bacteria (arrows). Nu: nucleus

bacteria (Tuomanen et al. 1986). After removal of the antibiotic, a reservoir of viable pathogens is likely to persist, particularly if some dormant bacteria are protected in an intracellular location. This would explain the resurgence of $R$. salmoninarum in populations of fish after antibiotic treatment had initially suppressed disease epidemics (Elliott et al. 1989). Also, live $R$. salmoninarum was toxic to MP and other leukocytes. Therefore, rapid intracellular growth of the bacterium would promote death of host cells which would be disadvantageous for its long-term survival in the fish and its subsequent vertical transmission.

Many of the attributes that contribute to the successful replication of the bacterium may be induced by the extracellular protein (antigen $F$, soluble protein) of Renibacterium salmoninarum (Getchell et al. 1985). This protein is associated with the cell surface, produced in prodigious quantities, and implicated in virulence (Bruno 1988) The major and best characterized component of the extracellular protein is a $57 \mathrm{kDa}$ pro- tein (p57) which has autoaggregating, hydrophobic, (Daly \& Stevenson 1990), leukoagglutinating and possibly, immunosuppressive properties (Turaga et al. 1987, Rockey et al. 1991, Wiens \& Kaattari 1991). Hydrophobic surface proteins promote phagocytosis by MP, an attribute made apparent by the rapacious uptake of the bacteria by the MP despite a lack of complement in the media. Wiens \& Kaattari (1991) note that the protein possesses characteristics similar to adhesion proteins which may allow bacterial attachment to cellular receptors. In our study, the adherence of $R$. salmoninarum to the plasma membranes of lymphocytes and erythrocytes supports this hypothesis. Perhaps this provides a means of systemic transportation. The hemolytic activity of the extracellular protein may also induce lysis of membranes (Evenden et al. 1990), allowing bacteria to escape from the phagolysosome. In addition, if $R$. salmoninarum can disrupt the plasma membrane of lymphocytes, as suggested by the micrographs, then this may explain the finding that 
purified p57 reduces antibody synthesis (Rockey et al. 1991). The lytic and adherent activities of the formalinkilled bacteria were diminished but not eliminated, either because the bacteria were no longer producing protein or because the pre-infection treatment had removed some of the extracellular protein. This could be why MP infected with killed $R$. salmoninarum survived longer and tolerated larger numbers of the bacteria.

Although Renibacterium salmoninarum has formidable defenses to survive intracellularly, the MP were capable of killing the bacterium, a result also noted by Bandin et al. (1993). The mixture of leukocytes in culture, including some previously exposed to the extracellular protein of $R$. salmoninarum, may have produced interleukins that activated bacterial killing by MP. However, neither interleukins nor activation of MP are required for the killing of intracellular pathogens (Crowle 1988, Dowling et al. 1992). Crowle (1988) suggests that some, but not all, MP in a population are able to kill intracellular Mycobacterium tuberculosis; thus the infection is perpetuated in vivo. This may also be true for $R$. salmoninarum in vivo. Moreover, we found that the MP phagocytosed melanin granules which might have improved the life-span of these cells, thereby increasing the odds of killing the bacteria. Ingestion of melanin by phagocytes may be a mechanism of protection against the effects of free radicals exuded from piscine neutrophils and tissue debris (Ellis 1982, Rowley et al. 1988, Ferguson 1989). Dispersed melanin and increased numbers of melanomacrophages (MP containing melanin) are characteristic of chronic inflammations in fish (Bruno 1988, Ferguson 1989), a condition duplicated in our primary cultures infected with live or formalin-killed $R$. salmoninarum. The internalized bacteria appeared unaffected by melanin and, may, like the MP, capitalize on its protective features to survive intracellularly.

Results of this work suggest the mechanisms that allow Renibacterium salmoninarum to perpetuate chronic infections of bacterial kidney disease and resist treatment by antibiotics and vaccines. Because of its cell surface components, $R$. salmoninarum is readily phagocytosed by MP and is able to move from the phagosome and into the cytoplasm. This mechanism does not require active growth (or even viability), and in concert with its durable cell wall $R$. salmoninarum may remain dormant in the cytoplasm of the MP. The MP appear to tolerate limited numbers of virulent intracellular $R$. salmoninarum, and extensive replication would result in loss of protective host cells. The success of $R$. salmoninarum as a pathogen likely results from its ability to survive in the cytoplasm of $\mathrm{MP}$ and maintain minimal replication until conditions favor maximum reinfection.
Acknowledgements. The authors thank $\mathrm{T}$ Kuncald and P. J. Connolly for their assistance with statistical analysis and computations, and the Oregon State University Fish Toxicology Laboratory for supplying fish for these experiments. This work was supported by grants provided by the Western Regional Aquaculture Consortium, Oregon Department of Fish and Wildlife (Anadromous Fish Act, PL89-304), Oregon Sea Grant (No. NA85AA-D-56095), and fellowships from the Atlantic Salmon Federation, Sports Fishıng Institute Fund and N. L. Tartar Fund. This is Oregon Agricultural Experimental Station technical paper no. 10672.

\section{LITERATURE CITED}

Austin B, Austin DA (1987) Aerobic Gram-positive rods. In: Laird LM (ed) Bacterial fish pathogens. Ellis Horwood Limited, Chichester, p 56-96

Bandin I, Ellis AE, Barja JL, Secombes CJ (1993) Interaction between rainbow trout macrophages and Renibacterium salmoninarum in vitro. Fish Shellfish Immunol 3:25-33

Banner CR, Long JJ, Fryer JL, Rohovec JS (1986) Occurrence of salmonid fish infected with Renibacterium salmoninarum in the Pacific Ocean. J Fish Dis 9:273-275

Braun-Nesje R, Bertheussen K, Kaplan G, Seljelid R (1981) Salmonid macrophages: separation, in vitro culture and characterization. J Fish Dis 4:141-151

Brittain DC (1987) Update on antibiotics 1. Erythromycin. Med Clin N Am 71:1147-1154

Brown LL, Iwama GK, Evelyn TPT, Nelson WS, Levine RP (1994) Use of the polymerase chain reaction (PCR) to detect DNA from Renibacterium salmoninarum within individual salmonid eggs. Dis Aquat Org 18:165-171

Bruno DW (1986) Histopathology of bacterial kidney disease in laboratory infected rainbow trout, Salmo gairdneri Richardson, and Atlantic salmon, Salmo salar L., with reference to naturally infected fish. J Fish Dis 9:523-537

Bruno DW (1988) The relationship between autoagglutination, cell surface hydrophobicity and virulence of the fish pathogen Renibacterium salmoninarum. FEMS Microbiol Lett 51:135-140

Buchmeier NA, Heffron F (1991) Inhibition of macrophage phagosome-lysosome fusion by Salmonella typhimurium. Infect Immun 59:2232-2238

Crowle AJ (1988) The tubercle bacillus-human macrophage relationship studied in vitro. In: Bendinell $M$, Friedman $H$ (eds) Mycobacterium tuberculosis interactions with the immune system. Plenum Press, New York, p 99-135

Daly JG, Stevenson RMW (1985) Charcoal agar, a new growth medium for the fish disease bacterium Renibacterium salmoninarum. Appl Environ Microbiol 50:868-871

Daly JG. Stevenson RMW (1990) Characterization of the Renibacterium salmoninarum haemagglutinin. J Gen Microbiol 136:949-953

Davis-Scibienski C, Beaman BL (1980) Interaction of Nocardia asteroides with rabbit alveolar macrophages: association of virulence, viability, ultrastructural damage, and phagosome-lysosome fusion. Infect Immun 28:610-619

Dowling JN, Saha AK, Glew RH (1992) Virulence factors of the family Legionaellaceae. Microbiol Rev 56:32-60

Elliott DG, Pascho RJ, Bullock GL (1989) Developments in the control of bacterial kidney disease of salmonid fishes. Dis Aquat Org 6:201-215

Ellis AE (1982) Differences between the immune mechanisms of fish and higher vertebrates. In: Roberts RJ (ed) Microbial diseases of fish. Academic Press, New York, p 1-29

Evelyn TPT (1977) An improved growth medium for the 
kidney disease bacterium and some notes on using the meduum. Bull Off Int Epiz 87:511-513

Evelyn TPT, Prosperi-Porta L, Ketcheson JE (1986) Experimental intra-ovum infection of salmonud eggs with Renibacterium salmoninarum and vertical transmission of the pathogen with such eggs despite their treatment with erythromycin. Dis Aquat Org 1:198-202

Evenden AJ, Gilpin ML, Munn CB (1990) The cloning and expression of a gene encoding haemolytic activity from the fish pathogen Renibacterium salmoninarum. FEMS Microbiol Lett 71:31-34

Farber JM, Peterkin PI (1991) Listeria monocytogenes, a foodborne pathogen. Microbiol Rev 55:476-511

Ferguson HW (1989) Systemic pathology of fish. Iowa State University Press, Ames, Lowa, p 3-10

Fountain MW, Weiss SJ, Fountain AG, Shen A, Lenk RP (1985) Treatment of Brucella canis and Brucella abortus in vitro and in vivo by stable plurilamellar vesicleencapsulated aminoglycosides. J Infect Dis 152:529-535

Fryer JL, Sanders JE (1981) Bacterial kidney disease of salmonid fish. Annu Rev Microbiol 35:273-298

Getchell RG, Rohovec JS, Fryer JL (1985) Comparison of Renibacterium salmoninarum isolates by antigenic analysis. Fish Pathol 20.149-159

Ghadially FN (1988) Ultrastructural pathology of the cell and matrix: a text and atlas of physiological and pathological alterations in the fine structure of cellular and extracellular components, 3rd edn, Vol. 1 Butterworth's, London, p 589-677

Goodfellow M. Embley TM. Austin B (1985) Numerical taxonomy and emended description of Renibacteium salmoninarum. J Gen Microbiol 131:2739-2752

Gutenberger SK (1993) Phylogeny and intracellular survival of Renibacterium salmoninarum. PhD thesis, Oregon State University, Corvallis, OR

Gutenberger SK, Giovannoni SJ, Fjeld KG, Fryer JL, Rohovec JS (1991) A phylogenetic comparison of the 16S rRNA sequence of the fish pathogen, Renibacterium salmoninarum, to Gram-positive bacteria. FEMS Microbiol Lett 77:151-156

Jones D, Krieg NR (1986) Serology and chemotaxonomy. In: Sneath PHA, Mair MS, Sharpe ME, Holt JG (eds) Bergey's manual of determinative bacteriology, Vol 2. The Williams \& Wilkins Co., Baltimore, p 979-982

Kiehlbauch JA, Albach RA, Baum LL, Chang LP (1985) Phagocytosis of Campylobacter jejuni and its intracellular survival in mononuclear phagocytes. Infect Immun 48:446-451

Kusser W, Fiedler F (1983) Murein type and polysaccharide composition of cell walls from Renibacterium salmoninarum. FEMS Microbiol Lett 20:391-394

Mbawuike IN, Luhr JE, Herscowitz HB (1986) Enhanced recovery of murine alveolar macrophages: morphological

Responsible Subject Editor: I P. T Evelyn, Nanaimo, British Columbia, Canada and functional characteristics following intravenous in jection of heat-killed Mycobacterium bovis BCG. Infect Immun 51:483-489

McDonough KA, Kress Y, Bloom BR (1993) Pathogenesis of tuberculosis: interaction of Mycobacterium tuberculosis with macrophages. Infect Immun 61:2763-2773

Mitchum DL, Sherman LE (1981) Transmission of bacternal kidney disease from wild to stocked hatchery trout. Can J Fish Aquat Sci 38:547-551

Riva A (1974) A simple and rapid staining method for enhancing the contrast of tissues previously treated with uranyl acetate. J Microsc (Paris) 19:105

Rockey DD, Turaga PSD, Wiens GD, Cook BA, Kaattari SL (1991) Serine proteinase of Renibacterium salmoninarum digests a major autologous extracellular and cell-surface protein. Can J Microbiol 37:758-763

Rowley AF, Hunt TC, Page M, Mainwaring G (1988) Fish. In Rowley AF, Ratcliffe NA (eds) Vertebrate blood cells Cambridge University Press, Cambridge, p 19-127

Sanchez MS, Ford CW, Yancey RJ (1986) Evaluation of antibacterial agents in a high-volume bovine polymorphonuclear neutrophil Staphylococcus aureus intracellular killing assay. Antimicrob Agents Chemother 29:634-638

Sawai T, Yamaki T, Ohya T (1976) Purification and some properties of Arthobacter globiformis exo-1,6-a-glucosidase. Agric Biol Chem 40:1293-1299

Sibley LD, Franzblau SG, Krahenbuhl JL (1987) Intracellular fate of Mycobacterium leprae in normal and activated mouse macrophages. Infect Immun 55:680-685

Stackebrandt E, Wehmeyer U, Nader H, Fiedler F (1988) Phylogenetic relationship of the fish pathogenic Renibacterium salmoninarum to Arthrobacter, Micrococcus and related taxa. FEMS Microbiol Lett 50:117-120

Tuomanen E, Durack DT, Tomasz A. (1986) Antibiotic tolerance among clinical isolates of bacteria. Antimicrob. Agents Chemother 30:521-527

Turaga PSD, Wiens GD, Kaattari SL (1987) Analysis of Renibacterium salmoninarum antigen production in silu. Fish Pathol 22:209-214

Watanabe S, Sasaki J, Wada T, Tanaka Y, Otsuka M (1988) Low gel temperature agarose encapsulation of small specimens for electron microscopy. J Electron Microsc 37:89-91.

Wiens GD, Kaattari SL (1991) Monoclonal antibody characterization of a leukoagglutinin produced by Renibacterium salmoninarum. Infect Immun 59:631-637

Yasutake WT, Wales JH (1983) Microscopic anatomy of salmonids: an atlas. Resource Publication 150, US Dept. of Interior, Fish and Wildlife Service, Washington, DC, p 183

Young CL, Chapman GB (1.978) Ultrastructural aspects of the causative agent and renal histopathology of bacterial kidney disease in brook trout (Salvelinus fontinalis). J Fish Res Bd Can 35:1234-1248

Manuscript first received: June 13, 1995

Revised version accepted: September 9,1996 